\title{
Evaluating the scale-up of a reactor for the treatment of textile effluents using Bjerkandera sp
}

\author{
Evaluación del escalamiento de un reactor para el tratamiento de efluentes textiles usando \\ Bjerkandera sp
}

\author{
María Isabel Gaviria-Arroyave ${ }^{1}$, Juliana Osorio-Echavarría ${ }^{2 *}$, Natalia Andrea Gómez-Vanegas ${ }^{2}$ \\ ${ }^{1}$ Dirección de Investigación, Escuela de Ingeniería de Antioquia EIA. km $2+200$ vía Aeropuerto José María Córdoba. A.A 055427. Envigado, \\ Colombia \\ ${ }^{2}$ Grupo de Investigación de Bioprocesos, Facultad de Ingeniería, Universidad de Antioquia. Calle 70 \# 52-21. A.A 050010. Medellín, \\ Colombia
}

\section{ARTICLE INFO:}

Received February 12, 2018

Accepted August 02, 2018

\section{KEYWORDS:}

White-rot fungi, industrial wastewater, dye, bioremediation, fixed bed

Hongos de la madera, Agua residual industrial, colorante, biorremediación, lecho fijo
ABSTRACT: Effluents from the textile industry have a negative environmental impact due to their high load of dyes and hard-to-remove compounds: additives, detergents, and surfactants; these must be treated before effluents can be discharged into water. White-rot fungi show great potential for the bioremediation of water and soil matrices contaminated with recalcitrant pollutants (these are generally toxic). In this work, we designed a $5 \mathrm{~L}$ fixed bed reactor and evaluated its performance on the degradation of pollutants in effluents from the textile industry in continuous-operation mode under non-sterile conditions, using ligninolytic fungus Bjerkandera sp. (anamorphic state R1). This setup was based on a previous design of a $0.25 \mathrm{~L}$ fixed-bed model bioreactor. The system was designed by taking into account the geometric and hydrodynamic similarities of both setups. In continuous-mode color-removal assays, the bioreactor was operated at a $36 \mathrm{~h}$ Hydraulic retention time (HRT), a $1 \mathrm{~L} / \mathrm{min}$ air flux at $33^{\circ} \mathrm{C}$, and a dye concentration of $75 \mathrm{~g} / \mathrm{L}$ (sulfur black 1) and $6.5 \mathrm{~g} / \mathrm{L}$ (indigo Vat blue 1). $69 \%$ of the dye was removed, and changes in the chemical structures of the dyes confirmed the ligninolytic activity of the microorganism as the main dye removal mechanism..

RESUMEN: Los efluentes provenientes de industrias textiles generan impactos ambientales negativos, debido a altas cargas de colorantes y compuestos de difícil remoción como aditivos, detergentes y surfactantes, los cuales deben ser tratados antes de ser descargados a cuerpos de agua. Los hongos ligninolíticos han mostrado gran potencial para procesos de biorremediación de aguas y suelos contaminados con compuestos recalcitrantes y generalmente tóxicos. Este trabajo, se enfoca en el diseño y evaluación del desempeño de un reactor de $5 \mathrm{~L}$ de lecho fijo para la degradación de efluentes de la industria textil en condiciones no estériles y operación continua, usando el hongo ligninolítico Bjerkandera sp. en su estado anamorfo R1. Dicha tecnología se desarrolló tomando como base para realizar el diseño un biorreactor modelo de lecho de fijo de 0,25 L. El sistema de $5 \mathrm{~L}$ se diseñó teniendo en cuenta la similitud geométrica e hidrodinámica. En los ensayos de decoloración en continuo el reactor se operó a un tiempo de retención hidráulica (TRH) de $36 \mathrm{~h}$, aireación de $1 \mathrm{~L} / \mathrm{min}$ y $33^{\circ} \mathrm{C}$, además de una carga de colorante de $75 \mathrm{~g} / \mathrm{L}$ para el Negro sulfuroso y 6,5g/L para índigo Vatblue; se alcanzó una decoloración del $69 \%$ y se identificaron cambios en las estructuras químicas de los colorantes presentes en el agua residual después del tratamiento, mostrando la actividad ligninolítica del microorganismo como el principal mecanismo de remoción de color.

\section{Introduction}

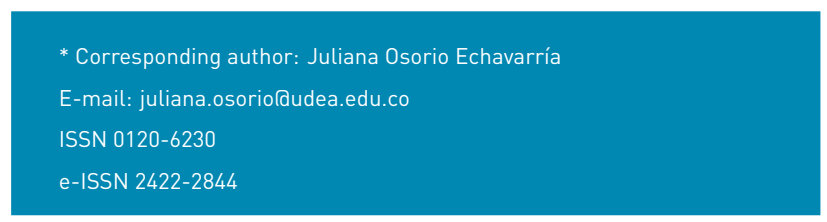

The textile industry generates a large load of pollutants due to its water-intensive processes $10.091 \mathrm{~m}^{3} / \mathrm{kg}$ of thread) [1] that create pollutant buildup during its different stages. The main sources of pollution are the washing 
and bleaching of natural fibers and the dyeing and finishing steps; these steps add impurities to water lwhich are added to make the threading and weaving processes easier) as well as auxiliaries and unattached dyes [2]. As the demand for diversified textile products increases, the amount and variety of polluted effluents does as well; these effluents are characterized by their high chemical oxygen demand (COD) and biochemical oxygen demand (BOD), as well as for their persistence in water -this characteristic is attributed to their complex aromatic structure and synthetic origin [3] that makes conventional wastewater treatment plants unable to deal with them effectively [4]. In water, dyes can become toxic and carcinogenic as some of them display chemical structures (azo type) that generate aromatic amines; these are associated with genetic mutations after they are metabolized by the liver and some microorganisms in the intestines of superior animals $[5,6]$. Polluted effluents can also display a considerable heavy metal or sulfur content and cause an increase in the concentration of salts, a change in $\mathrm{pH}$, and an all too unpleasant visual effect at concentrations as low as $0.01 \mathrm{ppm}[7,8]$.

One of the most used dyes in the industry are Vat dyes; these are known for their insolubility in water, low affinity to cellulosic fibers in their natural state, and demand of oxidation/reduction processes for their application to fibers [6]. In this group, the most representative dyes are those that possess a chemical structure that is either indigoid or anthraquinone. Indigoes are used for dyeing cellulosic fibers, mainly denim, and display a non-fixed percentage in water that varies between $5 \%$ and $15 \%$ [4]; their degradation is limited by the precipitation of the dye when reoxidized by the air or the stream [9].

Another widely used dye group in the dyeing of denim is the sulfur dye group; these are macromolecular compounds obtained from the treatment of structures such as aromatic amines and phenols containing sulfur and sodium polysulfide - black dyes represent $80 \%$ of sulfur dyes used in the industry. The process by which sulfur dyes are applied onto fibers is the same as for Vat dyes, as they have to be solubilized using sodium sulfur or a similar compound, which reduces the polysulfide bonds to mercaptan groups $[6,10,11]$. The degradation of sulfur dyes is a very complicated process as their sulfide group content, along with their high molecular weight, makes them very toxic for most studied microorganisms [4].

Several strategies have been proposed for the treatment of polluted effluents and the degradation of dyes; these are focused on physical and chemical treatments ladsorption, neutralization, chemical degradation, ozonation, membrane filtration, etc.) that display efficiencies of up to $90 \%$ [3]. Despite most advanced physical-chemical techniques (known as Advanced Oxidation Processes AOPJ displaying higher efficiencies, it has been proven that conditions in the process do vary a lot with each dye; this makes oxidation of real textile effluents quite tricky as components mix in the dyeing bath [12]. Also, in many cases, other toxic intermediate compounds appear, and the associated power consumption and cost of catalysts can be high [13]. Biological treatment has been recognized as an attractive alternative method for the treatment and degradation of dyes in highly polluted industrial wastewaters; besides being useful, it can be cost-competitive and environmentally friendly [14].

Now, textile effluents are treated aerobically and anaerobically using fungi and bacteria. Color-removal and mineralization-of-dye efficiencies of around $70 \%$ have been reported for anaerobic bacterial systems [11] and more than $80 \%$ for white rot fungi $[6,15]$. Many Basidiomycota and Ascomycota have been used in dye degradation; this is probably due to the resistance of the fungal mycelium to changes in $\mathrm{pH}$, temperature, nutrients, and aeration, on top of their rapid colonization of surfaces that allows an excellent job in immobilized systems. The key to active degradation with these microorganisms is based on their extracellular enzymatic activity, which depends on the formation of free radicals to ensure oxidative action on several substrates; this non-specificity enables oxidative action on different dyes and xenobiotic compounds such as pesticides and polychlorinated biphenyls (PCB) $[16,17]$.

In fungal treatment, a direct approach followed by the active culture of selected fungi or the purification of extracellular enzymes produced is used; the former presents the advantage of allowing researchers to skip the enzymatic purification step (which can be quite painful and expensive) $[18,19]$. In such cases, systems that favor enzymatic production are required along with the control of the most critical variables in the process. Some reactors used in fungal enzyme production or dye degradation are classified as Submerged Fermentation (SmF) and Solid-State Fermentation (SSF) technologies; in these we can find bubble columns, fluidized beds, biofilm flat-sheet, packed bed reactors, membrane reactors, and solid-state fermentation reactors (Rotating drum, Column, Koji-type, Stirred horizontal). One of the most used and promising $\mathrm{SmF}$ systems is the fixed bed reactor, wherein some authors report there are reactors (such as packed-bed and membrane reactors) that provide a microenvironment in which the nutrients create a natural gradient that delays primary metabolism while keeping most of the fungal biomass in the idiophase, increasing enzymatic production $[17,20]$. 
In this study, we developed a $5 \mathrm{~L}$ packed-bed reactor and evaluated its performance on the treatment of non-sterile textile effluents using immobilized white-rot fungi Bjerkandera sp. (anamorph state R1); a $0.25 \mathrm{~L}$ model reactor was used as the basis for the design of this reactor.

\section{Methodology}

\subsection{Microorganism and culture media}

White-rot fungus strain Bjerkandera sp. R1 was used and cryopreserved in pinewood splinters and bagasse. All fungi were donated by the Environmental Engineering and Bioprocesses Group from the department of chemical engineering at Universidad de Santiago de Compostela (Spain). The strain was previously identified as an anamorph of Bjerkandera $s p$. by Taboada-Puid et al., 2010., and is described as a saprophytic fungus of decaying wood and some conifers; it grows annually, and it is well distributed in North America and the tropics. The strain was identified as anamorphic based on its sequences of ribosomal DNA and morphological analysis showing lack of sexual forms and cylindrical conidia [20]. To reactivate the strain, we cultured it in Petri dishes using a maintenance medium culture: Agar (15 g/L), Glucose (10 $\mathrm{g} / \mathrm{L})$, malt extract $(3.5 \mathrm{~g} / \mathrm{L})$ and $\mathrm{pH}$ adjusted to 5.5 . The dishes were incubated at $30^{\circ} \mathrm{C}$ for eight days and kept at 4 ${ }^{\circ} \mathrm{C}$ until used.

\subsection{Inoculum preparation}

An inoculum was prepared from maintenance cultures by transferring 4 pieces of $9 \mathrm{~mm}$ agar to a $1.8 \mathrm{~L}$ Fernbach flask with $200 \mathrm{~mL}$ of a culture medium: glucose $(20 \mathrm{~g} / \mathrm{L})$, peptone ( $5 \mathrm{~g} / \mathrm{L})$, yeast extract ( $2 \mathrm{~g} / \mathrm{L}), \mathrm{KH}_{2} \mathrm{PO}_{4}(1 \mathrm{~g} / \mathrm{L}), \mathrm{MgSO}_{4} * 7 \mathrm{H}_{2} \mathrm{O}$ $(0.5 \mathrm{~g}) ; \mathrm{pH}$ was adjusted to 5.5 . The inoculum was incubated, statically, at $31^{\circ} \mathrm{C}$ for five days. Once incubation ended, the contents of the flask were mechanically stirred (at low speed, for 60 seconds) using a sterilized glass blender. The homogenized material was preserved at $4{ }^{\circ} \mathrm{C}$ until used in the color removal assays.

\subsection{Wastewater}

Wastewater in this study was obtained from a jean manufacturer located in Medellín, Colombia. The composition of water (per liter) was: Sulfur Black 1 dye [21] (150 g), Indigo Vat blue 1 dye [21] (13 g), Caustic Soda (80 g)), hydrosulfite $(1.5 \mathrm{~g})$ and a changing mixture of moisturizer and sequestrating agents (data not supplied by the manufacturer); $\mathrm{pH}$ was 11.5. For the color removal assays, $\mathrm{pH}$ was adjusted to 5.5 and Glucose $(2.5 \mathrm{~g} / \mathrm{L})$, and Peptone (1.25 g/L) were added. Continuous-mode color-removal assays were carried out in non-sterile wastewater diluted in a 1:2 ratio (wastewater: distilled water). The structure of the dyes is shown in Figure 1.

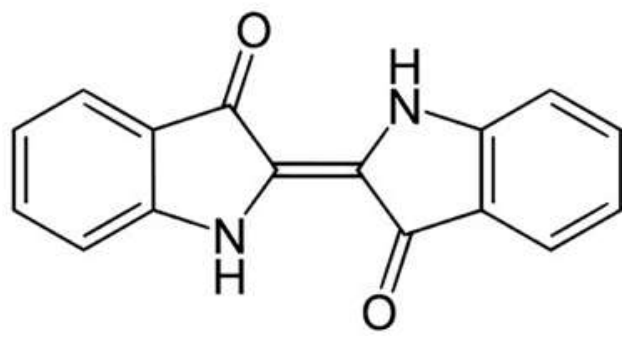

(a)<smiles></smiles>

(b)

Figure 1 Structure of indigo Vat blue 1 (a) [18] and Sulfur black 1 (b) [10]

\subsection{Reactor design}

For the scale-up of the $5 \mathrm{~L}$ reactor (real volume: 4.76 L), a system of $0.25 \mathrm{~L}$ was used as a basis, and geometrical similarity principles were applied; a 17:1 height-to-diameter ratio in the column was preserved (H:D). Hydrodynamics lespecially the axial dispersion phenomenon), were taken into account to preserve operation conditions during the color removal process. A residence time distribution (RTD) study was performed (data not shown) to establish an adequate level of aeration at the new scale in which the assays were made.

\subsection{Assembly of the reactor and testing}

The reactor was sterilized in three steps: i) a thorough steam cleansing at $121^{\circ} \mathrm{C}$; ii) a wash with two chemicals ( $7 \%$ sodium hypochlorite and $4 \%$ formaldehyde), and iii) a final rinse with an antibiotic solution $16 \mathrm{~mL}$ of Ceftriaxone sodium) to avoid bacterial contamination during the immobilization process; this last step was carried out in-situ after introducing the support $16 \mathrm{~cm}$ high $\times 7.5 \mathrm{~cm}$ wide sponge-gourd, previously sterilized). Sponge-gourd (Luffa cylindrica) is a natural lignocellulosic material, of low cost that is easy to manipulate; it is the fruit of one of the 
seven species of the Cucurbitaceae genre (climbing plants of tropical and subtropical climate) [22] . Sponge-gourd was selected from previous studies (data not shown) due to its high immobilization rate, low adsorption of dye, low dispersion module, less dead-zone volume in the system, and local availability favoring its industrial application.

To control the system's operational variables, peristaltic pumps and solenoid valves were used at the inlet and outlet of the system, at stable flow with PLC Samsung ${ }^{\circledR}$ time-controlled activation; at the same time, an "on/off" type valve was adapted to the control system to allow air in; this air was filtered through to $0.45 \mu \mathrm{m}$ syringe filter and entered the system in co-current flow in pulsating mode with a frequency of $0.01 \mathrm{~s}^{-1}$.

To evaluate the performance of the system on an effluent, the reactor was operated in continuous mode: $36 \mathrm{~h}$ Hydraulic Retention Time HRT, 1 liter per minute (L/min) aeration rate at $33{ }^{\circ} \mathrm{C}$ (regulated by a jacket in a thermostatic water bath); $2 \mathrm{~mL}$ samples were taken every $36 \mathrm{~h}$ (until $180 \mathrm{~h}$ were completed) with a sterile syringe in each of the ports as well as the outlet to be processed for color removal, enzymatic activity, and degradation products as is indicated in the following section.

\subsection{Analytical methods}

\section{Color removal and enzymatic activity}

The samples taken every $36 \mathrm{~h}$ (HRT) were analyzed in a Thermo Spectronic Helios Alpha spectrophotometer (analyzed range: $200 \mathrm{~nm}-800 \mathrm{~nm}$ ), and the percentage of dye removed was determined with the following Equation (1)

$$
D=\frac{\left(A_{i}-A_{f}\right)}{A_{i}} \times 100
$$

In Equation (1), $A_{i}$ is the value of the area under the curve at the initial time of degradation, $A_{f}$ is the value of the area under the curve at the final time of degradation, and $D$ is the color removal (\%).

The activity of the primary enzymes (Manganese Peroxidase - MnP, Lignin Peroxidase - LiP, Laccase and Versatile Peroxidase - VP) associated to degradation by white-rot fungi was monitored in a Thermo Spectronic Helios Alpha spectrophotometer using the same method as described by [23]. An activity unit (AU) is defined as the amount of enzyme (in $\mathrm{mL}$ ) needed to oxidize $1 \mu \mathrm{mol}$ of substrate per minute (DMP for MnP, ABTS for Laccase and Veratryl Alcohol for LiP).

\section{Analysis of degradation products}

The samples taken from the continuous-mode treatment were filtered through a $0.45 \mu \mathrm{m}$ syringe filter and then centrifuged at $6000 \mathrm{rpm}$ for $20 \mathrm{~min}$; the supernatant was mixed with ethyl acetate in a 1:1 ratio (to extract the organic fraction) and agitated in a vortex for $5 \mathrm{~min}$. The organic phase was separated, and then, anhydrous $\mathrm{Na}_{2} \mathrm{SO}_{4}$ was added to eliminate humidity on the sample.

Analysis by liquid chromatography (LC) was performed in a Thermo Scientific Accela 600 chromatograph with a C18 column; mobile phase: $A=3 \mathrm{mM}$ Triethylamine (TEA) $\mathrm{pH}$ 6.2 and $B=$ Acetonitrile $(A C N)$ : Methanol $(\mathrm{MOH})(50: 50)$, gradient elution $10 \% \mathrm{~A}$ and $90 \% \mathrm{~B}$, flow speed $1 \mathrm{~mL} / \mathrm{min}$, and an injection volume of $10 \mathrm{~mL}$. The temperature inside the column was $25^{\circ} \mathrm{C}$.

For the infrared spectroscopy analysis, the samples taken at $180 \mathrm{~h}$ of treatment were slowly frozen in decreasing gradients $\left(-20^{\circ} \mathrm{C},-80^{\circ} \mathrm{C}\right)$ and further freeze-dried for 24 $h$; the freeze-dried samples were analyzed in a Thermo Scientific Nicolet model iS10 spectrometer.

\section{Results and discussion}

\subsection{Reactor design and construction}

Hydrodynamics at the inside of the tubular packed bed reactor (especially axial dispersion) were fundamental to preserve good color-removal performance when the system was being scaled up. To design a $5 \mathrm{~L}$ reactor, we took a $0.25 \mathrm{~L}$ model and performed a hydrodynamic characterization of it, considering seven variables that were crucial to its performance; these are shown in Table 1.

Thanks to the dimensional analysis method [26], we established groups and ratios between these variables; this allowed us to find an expression that would correlate the Peclet-particle (Pep) and Reynolds-particle (Rep) numbers, (diffusive forces versus viscous forces) $[23,27]$. Considering this expression, we manipulated the geometrical variables involved in the construction of a prototype reactor -especially the relationship between its length (L), diameter (d) and the diameter of the particles (dp)- by applying geometrical similarity principles to preserve the values of those ratios with respect to the $0.25 \mathrm{~L}$ model reactor. Since L:d ratios above 10 decrease dispersion in the system (which favors mass transfer and thus color removal) [28], we decided to keep ours at 17; we also varied the spacing of the support to preserve a void fraction in-between scales.

Looking at Equation 2, it was evident that we had to calculate another crucial ratio in the design of the 5 $L$ reactor -superficial velocity of the liquid $\left(V_{L}\right)$ over superficial velocity of the gas $\left(V_{g}\right)$ (which also had to be maintained according to the values of the model reactor); 
Table 1 Variables that influence axial dispersion. Own sources

\begin{tabular}{ll}
\hline Variable & Hydrodynamic Influence \\
\hline Reactor length (L) & $\begin{array}{l}\text { The value of axial dispersion can vary along the reactor bed [24]. } \\
\text { ratio L/d must stay above } 10 \text { for tubular reactors. }\end{array}$ \\
\hline $\begin{array}{l}\text { Reactor diameter (d) } \\
\text { Particle diameter (dp) } \\
\text { reactor wall and can affect dispersion [20]. Non-spherical particles } \\
\text { provide a higher dispersion. }\end{array}$ \\
\hline Superficial velocity of the liquid (VL) & $\begin{array}{l}\text { Some authors suggest that velocity influences dispersion [20]; however, } \\
\text { others suggest the opposite and relate it to the flattening of the velocity. } \\
\text { profile when nearing turbulent flow. }\end{array}$ \\
\hline Superficial velocity of the gas $(\mathrm{Vg})$ & It increases dispersion, specifically in the pulsating system. \\
\hline Density of the fluid $(\rho)$ & For very dense fluids, dispersion increases due to the effect of gravity [25]. \\
\hline Viscosity of the fluid $(\mu)$ & It influences hydrodynamics at low Rep values. \\
\hline
\end{tabular}

Table 2 Relevant parameters in the model $(0.25 \mathrm{~L})$ and prototype $(5 \mathrm{~L})$ reactors

\begin{tabular}{ccc}
\hline Scale (L) & 0.25 & 5 \\
Scale factor & - & 2.8 \\
Empty fraction & 0.78 & 0.78 \\
Effective volume (L) & 0.22 & 4.76 \\
VL (cm/min) & 0.02 & 0.06 \\
Vg (cm/min) & 10.80 & 30.30 \\
Pep & 0.55 & 0.58 \\
Rep & 7.92 & 61.46 \\
\hline
\end{tabular}

in the assays carried out in the $0.25 \mathrm{~L}$ model reactor (data not shown), the importance of air to control the growth of the microorganism was made evident; however, its precise manipulation was difficult.

$$
P e_{p}=k\left(\frac{d_{p}}{L}, \frac{d_{p}}{d}, \frac{V_{L}}{V_{g}}, R e_{p}\right)
$$

For this reason, air played a key role in the design of the reactor, as control over the growth of Bjerkandera sp. (anamorph R1) required pulses that favored the microenvironments in the hyphae and also the production of ligninolytic enzymes without causing clogging [16]; in addition, axial dispersion was decreased (favoring hydrodynamics) by using an inlet system for liquid and gas in co-current from the lower end; we opted to design this inlet at an inclination of $35^{\circ}$ to decrease pressure at this point, avoiding flooding of the line. In a real representation of the system, as shown in Figure 2, the head displays a greater diameter than the body; we made this to facilitate the separation of the liquid and gas phases - we also added holes to the lid and along the body to this end. Besides that, we used equidistant ports and a jacket to control temperature. The real volume of the system was $4.76 \mathrm{~L}$. Table 2 summarizes the main variables of interest found in the model ( $0.25 \mathrm{~L}$ reactor) and the prototype ( $5 \mathrm{~L}$ reactor).
Despite sponge-gourd being an organic support, it varies greatly in shape and internal distribution of its channels - this is a nuisance factor; we maintained the distribution of the pieces at the inside of the reactor as to achieve an ensemble that was a little bit more receptive and decreased the effect of the irregular geometry of non-commercial supports on the dispersion of the effluent in a packed bed reactor. To control the effect of supports on the hydrodynamics of a reactor, several authors have analyzed the influence of commercial and non-commercial supports on tubular reactors, finding that values of the dispersion modules change from one ensemble to another due to their random nature; nevertheless, the tendency of the curves in the residence-time distribution assays are the same $[25,29]$.

\subsection{Reactor assembly and testing}

The continuous-mode color-removal assays showed that the reactor removed $69 \%$ of the dye after $180 \mathrm{~h}$ of treatment. UV-vis spectra reported the disappearance of a peak around $680 \mathrm{~nm}$, attributed to the dyes present in wastewater (Figure 3). After $100 \mathrm{~h}$, the system began to stabilize (HRT 3), we expect this to be related to the stabilization of the microorganism's growth, which has a doubling time of $23 \mathrm{~h}$; this time is associated with the stabilization of residual glucose in the system (Figure 4) that happened after HRT 2, indicating that the microorganism could have adapted to the new growth conditions [30]. The high doubling time and the unfavorable conditions that the microorganism needs to endure (non-sterile wastewater, high contaminating loads, high salt concentrations, among others) make it evident that the process needs to be optimized before considering industrial scale-up $[6,31]$.

Figure 5 shows the drastic change in effluent color, which corresponds to the obtained efficiency $(69 \%)$. We monitored the enzymatic activity of the microorganism 

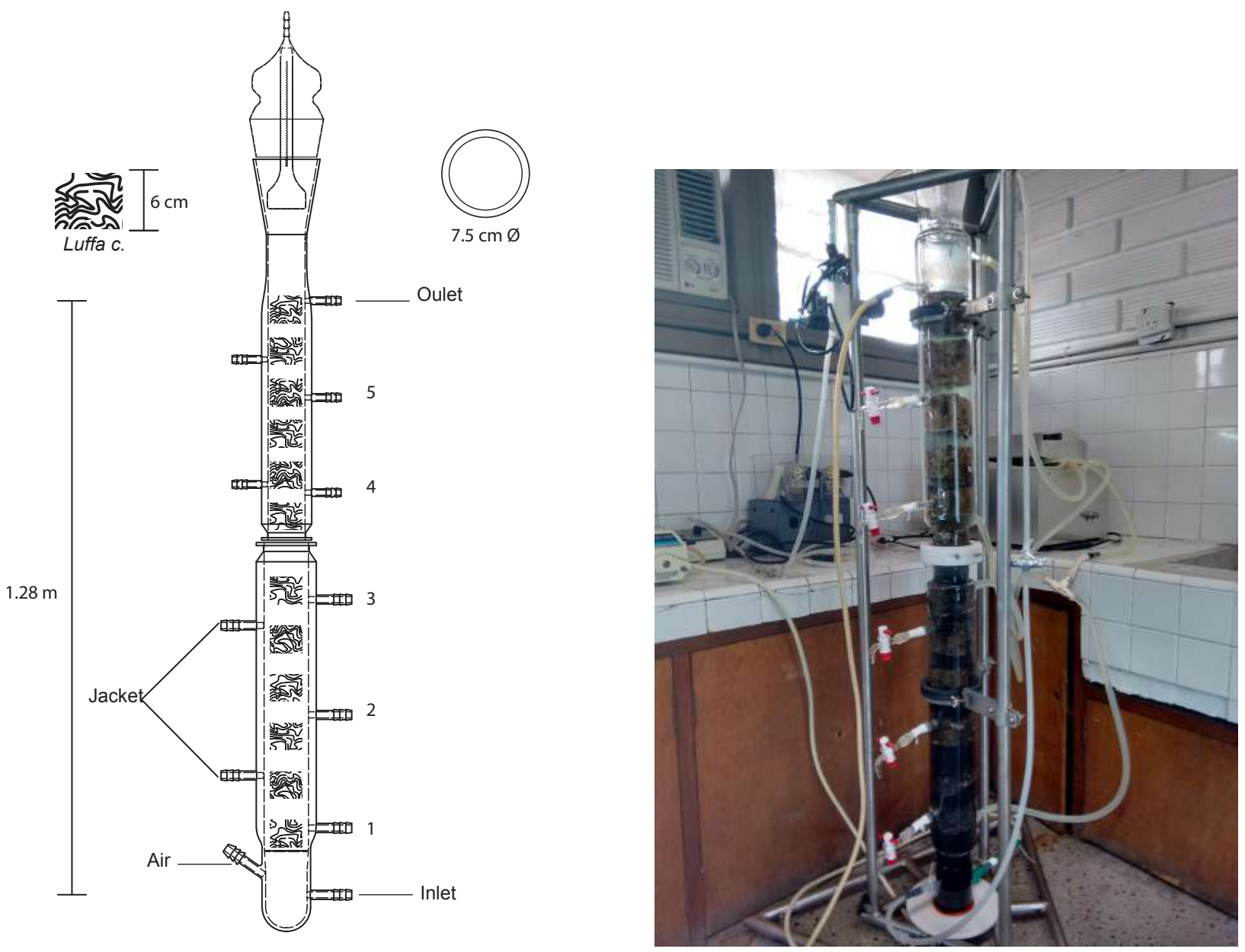

(a)

(b)

Figure $25 \mathrm{~L}$ packed-bed reactor loaded with sponge-gourd. al schematic and b) prototype

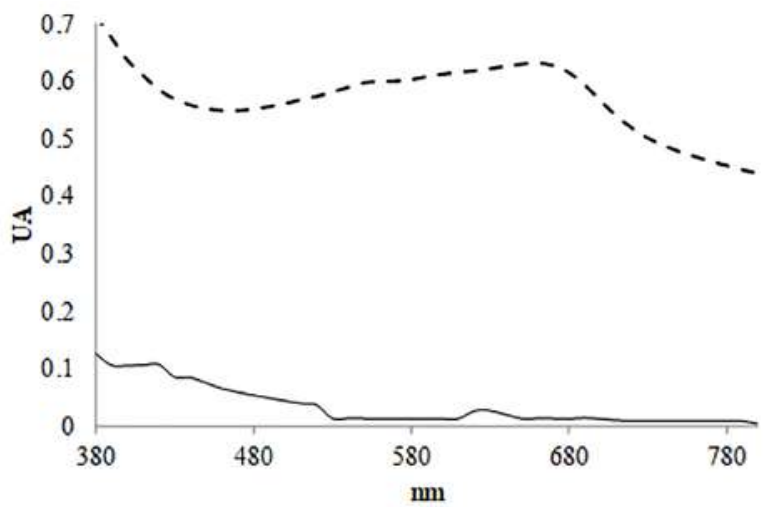

Figure 3 UV-vis spectra of the untreated effluent $(-)$ and $180 \mathrm{~h}$ after treatment (-), data obtained from the $5 \mathrm{~L}$ reactor

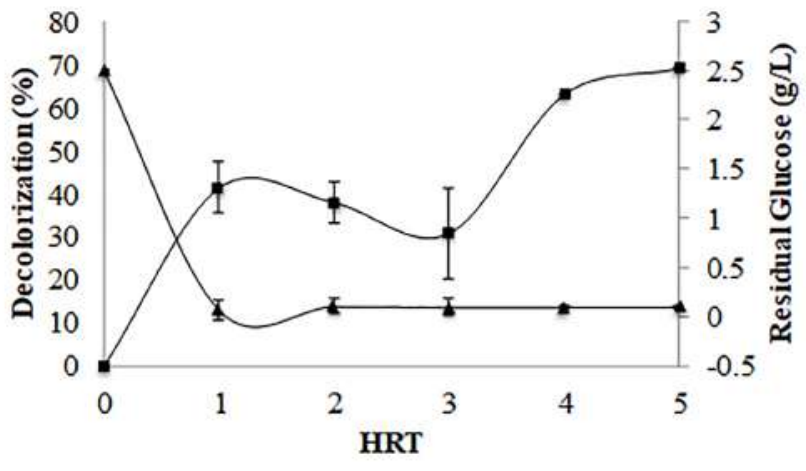

Figure 4 Relationship between residual glucose ( $\mathbf{\Delta}$ ) and color removal ( $\mathbf{\square}$ ) at the outlet 


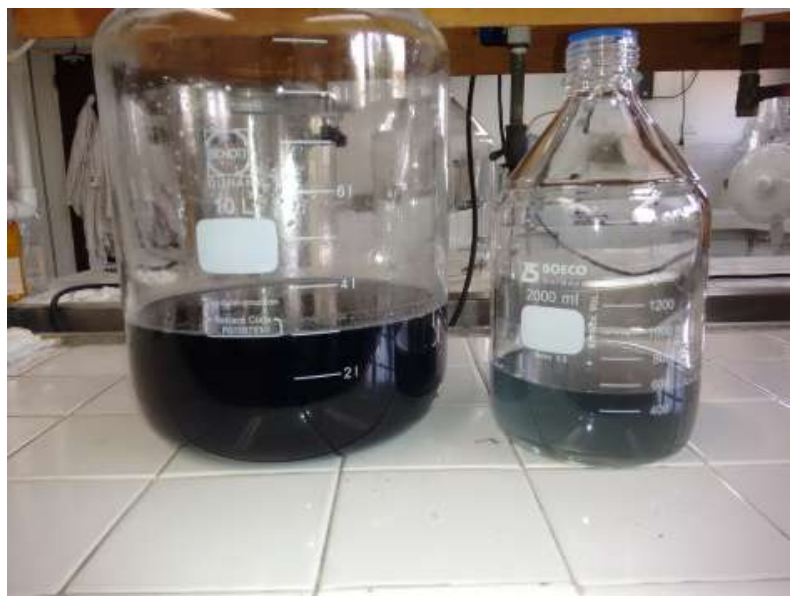

Figure 5 Close-up: wastewater, before treatment (left) and after $180 \mathrm{~h}$ of treatment in the $5 \mathrm{~L}$ reactor with Bjerkandera $s p$ (anamorph R1) (right)

and found that there was not a considerable production of peroxidases and laccases, despite the effectiveness of Bjerkandera $s p$ to remove the dye. Versatile peroxidase was the most prevalent enzyme (11.62 UA \pm 3.92$)$ followed by Laccase (4.38 UA \pm 0.78 ), LiP (0.54 UA \pm 0.14$)$ and, lastly, MnP, which is nearly undetectable $0.26 \mathrm{UA} \pm$ 0.10). Versatile Peroxidase uses the traditional multistep oxidation system of LiP and $\mathrm{MnP}$, which is based on the flow of the two electrons at the expense of $\mathrm{H}_{2} \mathrm{O}_{2}$. Versatile Peroxidase displays high affinity for $\mathrm{H}_{2} \mathrm{O}_{2}, \mathrm{Mn}^{2+}$, hydroquinone, and dyes; and a low affinity to veratryl alcohol and substituted phenols. This enzyme also shows multiple advantages such as the oxidation of substrates with high and low redox potential, as well as the capacity to degrade recalcitrant xenobiotic compounds such as 2,4-dichlorophenol, polycyclic aromatic hydrocarbons (PAHs) and lignin polymers $[19,31]$; this is the reason why its presence in this study turned out to be positive.

Despite enzymatic activity being low (which is related to the use of non-sterile wastewater), the presence of native flora might have generated compounds that destabilized the fungal enzymatic complex or the proteases that degraded these enzymes [23, 32]. This hypothesis is reinforced by a previous study that used the same microorganism (although on a different effluent) and was effective in non-sterile conditions [23]; in that study, the activities of $\mathrm{MnP}$ and LiP went from 146 and $116 \mathrm{U} / \mathrm{L}$ in sterile conditions to 1.5 and $14 \mathrm{U} / \mathrm{L}$ in non-sterile conditions, using a (polyurethane foam)-immobilized fungus, while keeping an eye on $\mathrm{pH}$ and supplementing the effluent just as we did. Despite this, a 60\% color removal efficiency was achieved, proving that for some species of white rot fungi, it is not possible to establish a direct correlation for enzymatic activity and color removal, as enzymatic mechanisms also include the generation of free radicals and the participation of other enzymatic complexes such as cytochrome p450 intracellular system [33]. It is evident then that we need to shed some light on the degradation mechanism used by the fungus, as well as the role of its enzymes, as it has been previously reported that, in addition to extracellular oxidizing complex, intracellular cytochrome p450 might also have an effect in effluent degradation land this one is difficult to quantify using non-molecular methods) [34]. Also, we have found studies on the correlation between main ligninolytic enzymes activity and the degradation of several recalcitrant compounds, including (PCBs) and dyes; this is the case of some authors [35] who conclude there is a direct correlation between the degradation rate of acid black and R016 dyes and the increased production of $\mathrm{MnP}$; he also found that other dyes like drimarene can be degraded easily at low enzymatic activity or via alternative mechanisms. Lastly, studies made with closely related organisms like Bjerkandera adusta [36] show that by using packed bed reactors, efficiencies of over $80 \%$ can be achieved, despite enzymatic activity being higher than what is reported in our study; in those studies, the authors emphasize that it may not always be possible to correlate a high enzymatic activity with a high color removal efficiency. It is evident then that more studies are needed to elucidate the role of cytochrome p450 intracellular system, but given the goal of our research was the industrial scale-up of the degradation process, we decided to pay more attention to the efficiency and feasibility of said process than to figure out what the enzymatic mechanisms were; not denying that they can play a fundamental role in the optimization and biochemical modeling at a white box level.

After $100 \mathrm{~h}$ of treatment (HRT 3), the system became stable, and we analyzed the color removal, enzymatic production, and sugar consumption profiles from samples taken from the five ports located in the body. The results showed that the reactor was active along the whole length of its body and that color removal increased from one section to the next, except in the case of ports 2 and 3 (Figure 6). The analysis of enzymatic activity at the ports, showed that both Laccase and Versatile Peroxidase were the most prevalent enzymes but, as Laccase gradually increased (reaching its highest point at port four), Versatile Peroxidase increased only up to the first port and then began to decrease (Figure 6); the residual glucose value remained then below $0.1 \mathrm{~g} / \mathrm{L}$ in all the ports, reaching said value only at the outlet. This behavior differs from the $0.25 \mathrm{~L}$ reactor, where the residual glucose value was zero in every port from HRT 3 onward; we expect this could have happened due to the morphological changes to the microorganism, as some authors have studied [37] that some white-rot fungi have genes that can either be activated or deactivated during an immobilization process when their conformation changes from pellet to biofilm. 


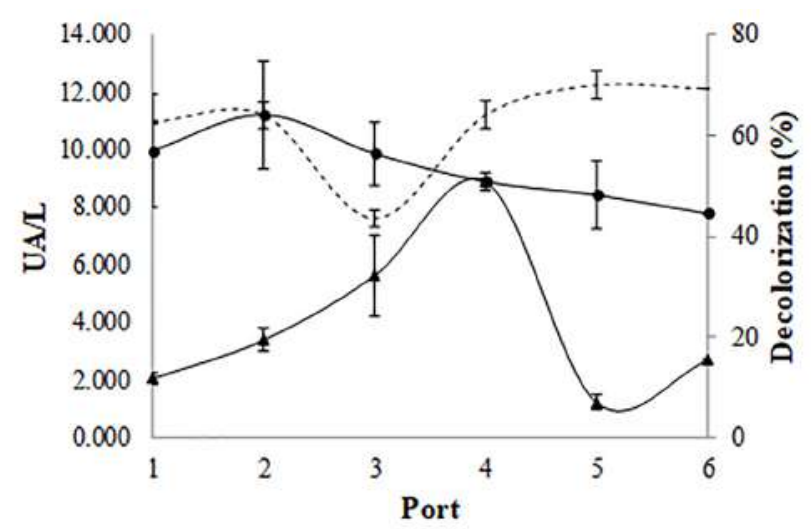

Figure 6 Enzymatic profile for Laccase ( $\mathbf{\Delta}$ ), Versatile peroxidase $(\bullet)$, and color removal percentage (-) in several ports of the $5 \mathrm{~L}$ reactor after $180 \mathrm{~h}$ of treatment with Bjerkandera $\mathrm{sp}$ lanamorph

R1)

We also expect that the reduction in glucose consumption (high residual glucose) in the last section of the reactor (ports five and six) might have caused a reduction in the enzymatic activity of the microorganism, and even though we observed a slight increase for Laccase in this section, we expect this to be related to the lower mass of fungus at the upper section of the system, given it is operated in ascendant flow.

When comparing the enzymatic activity and color removal profiles, we observed that color removal reaches its peak $169 \%$ ) around ports four and five, agreeing with Laccase, and staying almost stable during the rest of the treatment; the fact that from port four onward color removal does not increase noticeably suggests that "a dead section" or "a section with a smaller mass of microorganism" possibly hinders the efficiency of the system. It is evident then that the scale-up configuration has affected the morphology and performance of the microorganism; this is further suggested by the fact that in the $0.25 \mathrm{~L}$ model reactor, the main enzyme in charge of the degradation was Versatile Peroxidase (data not shown) whereas in the $5 \mathrm{~L}$ reactor the axial follow-up suggested it was Laccase.

As for the degradation products, the analyses performed by liquid chromatography HPLC (Figure 7) showed a consistent reduction in the peak associated with the dyes $(7.685 \mathrm{~min})$; the analysis also detected peaks at very low retention times $(0.9$ and $1.905 \mathrm{~min}$ ), that we expect correspond to intermediary compounds from the degradation of indigo dye, such as isatin (1 $\mathrm{H}$-indole-2,3-dione) and substituted indoles, as these are highly soluble in organic solvents such as methanol, acetone, acetonitrile, and ethyl acetate [38]. We also expect these peaks could be related to sulfur black 1 dye; despite its high presence in the dye bath and its

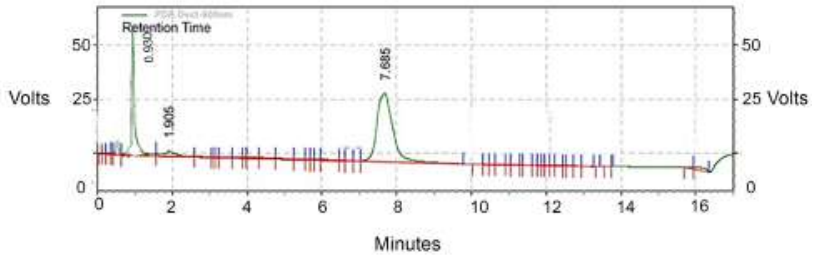

(a)

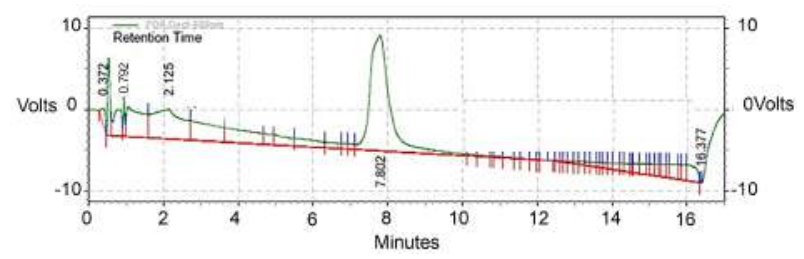

(b)

Figure 7 Chromatograms of raw wastewater al after $180 \mathrm{~h}$ of treatment, and b) in the $5 \mathrm{~L}$ reactor with Bjerkadera $s p$

(anamorph R1)

extensive use in the dyeing of cotton [39], we found no studies focused on establishing the enzymatic or physical-chemical degradation pathways -we expect this to be related to its complex structure. A study made by Feng Lin et al. [40], shows the use of photo-catalysis techniques in the degradation of aromatic structures containing sulfur, such as Thiophene and Benzothiophene (present in petroleum and gasoline), which results in the oxidation of sulphones, and in some cases, processes of mineralization with conversions of up to $93 \%$ [40]; these results suggest an alternative degradation pathway for this type of compounds. It is convenient then to perform more studies to establish the degradation pathways of sulfur dyes used in the denim dyeing industry. In addition, we analyzed the spectra of the effluent before and after treatment (Figure 8), and found that the main changes in spectra are present in the zone ranging from $1600 \mathrm{~cm}^{-1}$ to $500 \mathrm{~cm}^{-1}$; these spectra were also compared to the isatin spectrum taken from the National Metrology Institute of Japan (NMIJ) [41]. Several authors have reported the possible pathways for the oxidative degradation of indigo and indigo carmine dyes, suggesting isatin and anthranilic acid as the main stable intermediary compounds for chemical and enzymatic processes (the latter using laccase) [42]. In our comparison of the spectra, we noticed a resemblance between the spectrum of the treated effluent and that of isatin (especially in the specified zone), but we also noticed the absence of a peak attributed to the $\mathrm{C}=0$ bond lamong other variants) that might indicate the presence of intermediary compounds (based on isatin) that carry some substituents. These results agree with the analysis by HPLC, due to the polarity and some other characteristics of isatin and other indole-like. 


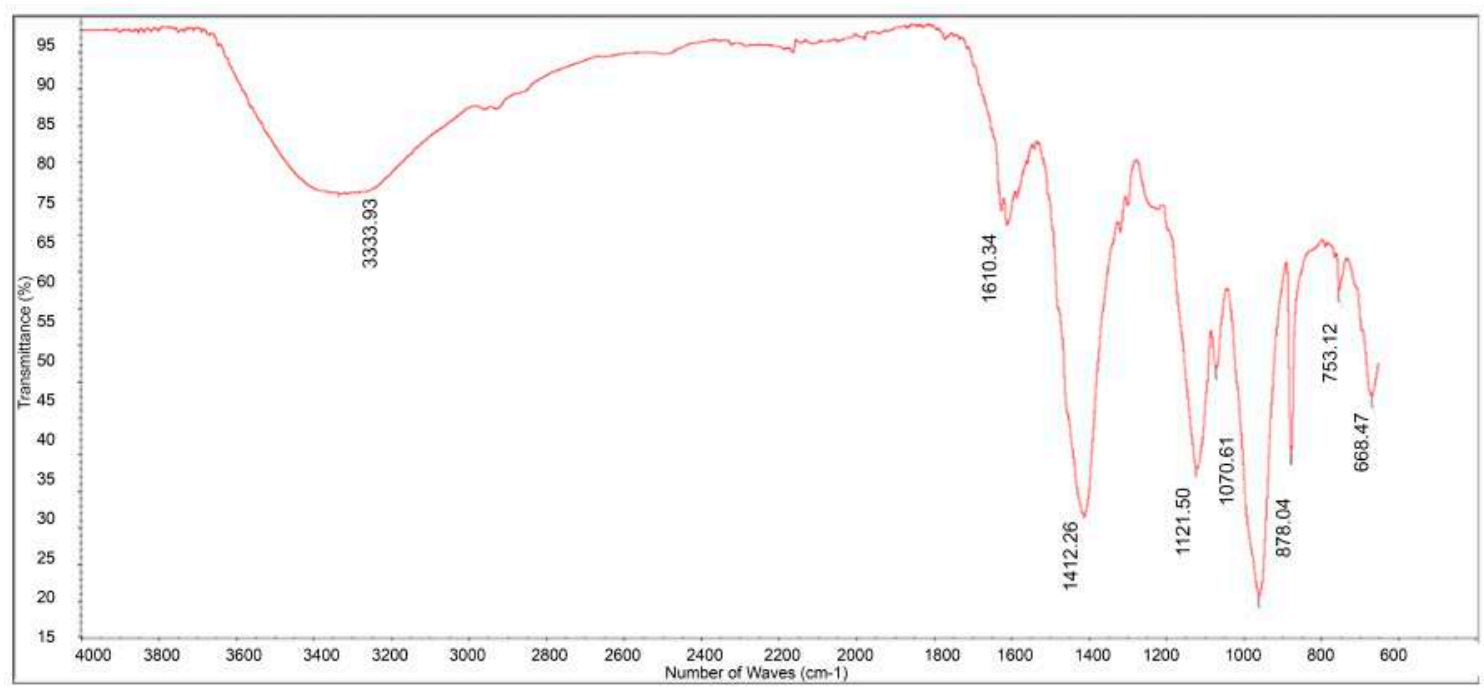

(a)

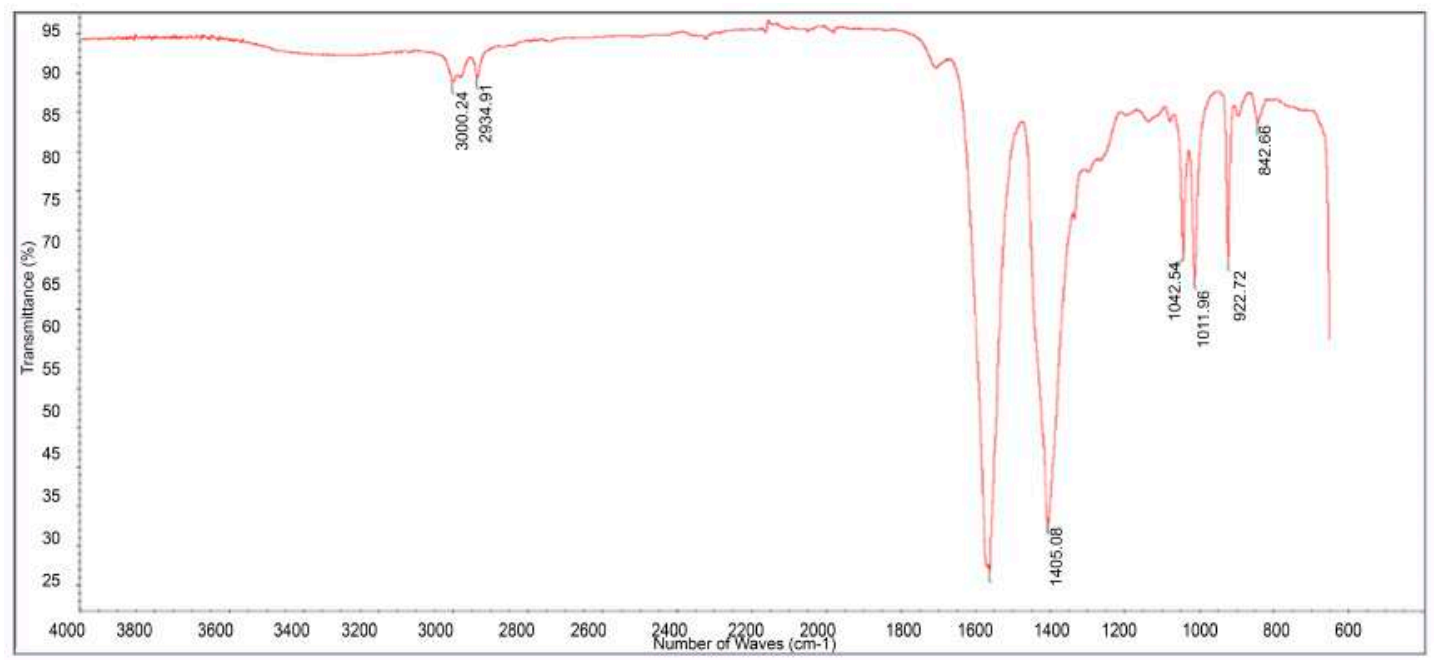

(b)

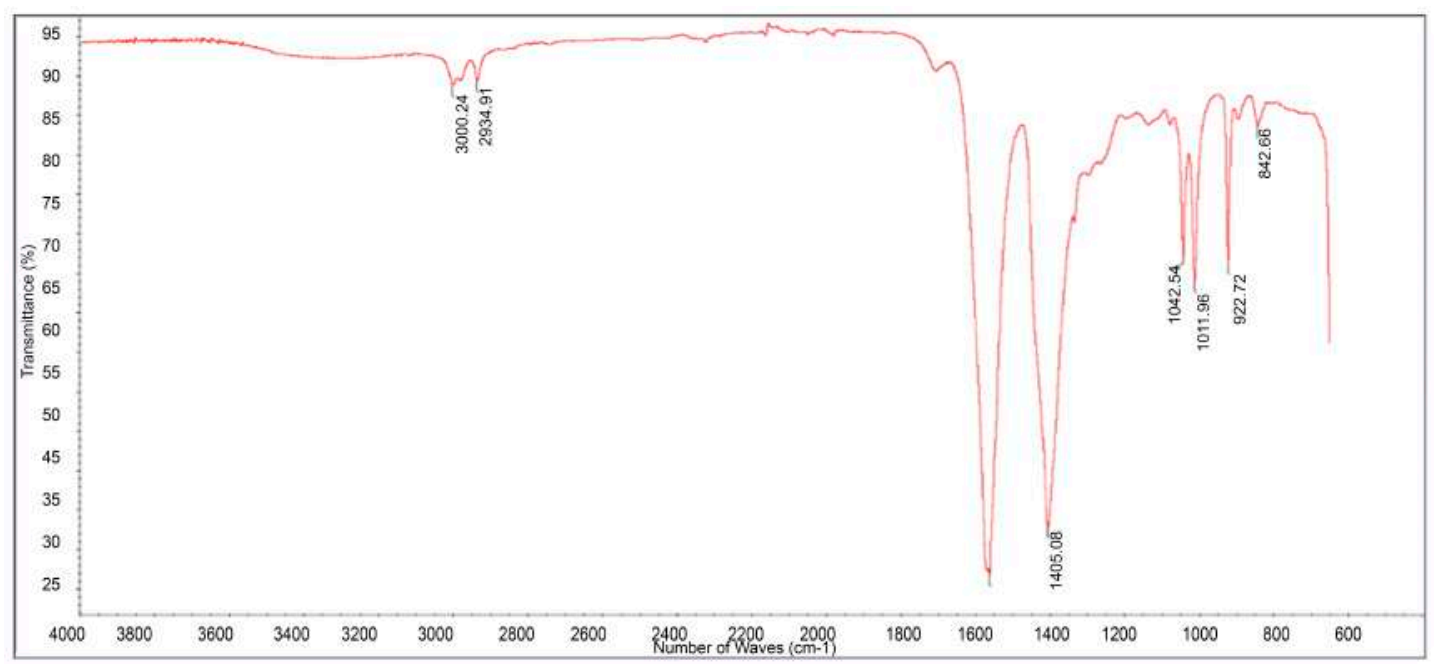

(c)

Figure 8 Infrared spectra for al wastewater before treatment, b) wastewater after $180 \mathrm{~h}$ treatment and c) isatin as intermediary 


\section{4. conclusions}

White-rot fungus Bjerkandera sp. (anamorph R1) shows excellent capacity to degrade textile wastewater under real non-sterile conditions, remaining stable for over seven days of operation and possibly degrading the dye structures present in wastewater. When we operated the system in continuous mode, color removal peaked at $69 \%$; we expect this effect to be related to the flow within the channels in sponge-gourd and the extended contact times derived from extended treatment $136 \mathrm{~h}$ Hydraulic Retention Time). The main enzymes involved in the process were laccase and versatile peroxidase; though their activity values were low, the hypothesis for the involvement of other mechanisms in the degradation of dyes raises a point for discussion.

As for the hydrodynamics and the scale-up parameters, the color removal process in the $5 \mathrm{~L}$ reactor used a 0.58 Peclet-particle number, which is very close to the number used in the model reactor ( $P e p=0.55$ ); this evidences that, in tubular fixed bed reactors, aeration affects the dispersion of the effluent greatly due to the associated bubble phenomena.

Despite the low activity values of the enzymes, we obtained a better distribution of Lacasse when maintaining dispersion in-between scales, suggesting the role of the enzyme in color removal at this new scale, and also, the feasibility of the axial dispersion phenomenon as a tool for the industrial scale-up of packed bed reactors.

\section{Acknowledgments}

We, the authors, would like to acknowledge the Bioprocesos research group at Universidad de Antioquia, Centro Tecnológico de Gestión Industrial Sena, Antioquia division, and the Innovation Fund (Gestión Tecnológica) at Universidad de Antioquia.

\section{References}

[1] A. P. Restrepo and et al., Evaluación técnica y económica de tecnologías para reuso de aguas de proceso en industrias de los sectores alimentos, textil, curtiembres y galvanoplastia, 1st ed. Medellín, Colombia: IMPREGÓN S.A, 2005.

[2] T. A. Nguyen and R. S. Juang, "Treatment of waters and wastewaters containing sulfur dyes: A review," Chemical Engineering Journal, vol. 219, pp. 109-117, Mar. 2013.

[3] H. Hayat, Q. Mahmood, A. Pervez, Z. A. Bhatti, and S. A. Baig, "Comparative decolorization of dyes in textile wastewater using biological and chemical treatment," Separation and Purification Technology, vol. 154, pp. 149-153, Nov. 2015.

[4] J. Khatri, P. V. Nidheesh, T. S. Anantha, and M. Suresh, "Advanced oxidation processes based on zero-valent aluminium for treating textile wastewater," Chemical Engineering Journal, vol. 348, pp. 67-73, Sep. 2018.
[5] A. Anastasi and et al., "Decolourisation and detoxification in the fungal treatment of textile wastewaters from dyeing processes," New Biotechnology, vol. 29, no. 1, pp. 38-45, Dec. 2011.

[6] X. L. He and et al., "Efficient degradation of azo dyes by a newly isolated fungus Trichoderma tomentosum under non-sterile conditions," Ecotoxicology and Environmental Safety, vol. 150, pp. 232-239, Apr. 2018.

[7] M. A. Amoozegar, M. Hajighasemi, J. Hamedi, S. Asad, and A. Ventosa, "Azo dye decolorization by halophilic and halotolerant microorganisms," Annuals of Microbiology, vol. 61, no. 2, pp. 217-230, Jun. 2011.

[8] M. Bilal, M. Iqbal, H. Hu, and X. Zhang, "Mutagenicity, cytotoxicity and phytotoxicity evaluation of biodegraded textile effluent by fungal ligninolytic enzymes," Water Science \& Technology, vol. 73, no. 10, pp. 2332-2344, May 2016.

[9] M. Solís, A. Solís, H. I. Peréz, N. Manjarrez, and M. Flores, "Microbial decolouration of azo dyes: A review," Process Biochemistry, vol. 47, no. 12, pp. 1723-1748, Dec. 2012.

[10] J. Pérez, J. Valldeperas, M. J. Lis, J. A. Navarro, and I. Conde. (2006) Reducción electroquímica de colorantes sulfurosos vías de proceso. [Online]. Available: https://upcommons.upc.edu/bitstream/handle/ 2099/4693/7reducci\%F3n+electroqu\%EDmica.pdf;jsessionid= B20A5928A8735173FE5EBF0CC1C2C823? sequence =1

[11] R. C. Garzon, “Cinética de degradación de colorantes textiles de diferentes clases químicas por hongos y bacterias inmovilizados en fibra de Agave tequiliana webber var azul," M.S. thesis, Fac.Ing., Pontificia Universidad Javeriana, Bogotá, Colombia, 2009.

[12] Y. S. Al-Degs, M. I. El-Barghouthi, A. H. El-Sheikh, and G. M. Walker, "Effect of solution ph, ionic strength, and temperature on adsorption behavior of reactive dyes on activated carbon," Dyes and Pigments, vol. 77, no. 1, pp. 16-23, 2008.

[13] E. Forgacs, T. Cserháti, and G. Oros, "Removal of synthetic dyes from wastewaters: a review," Environment International, vol. 30, no. 7, pp. 953-971, Sep. 2004.

[14] J. F. Osma, J. L. Toca, and S. Rodríguez, "Cost analysis in laccase production," Journal of Environmental Management, vol. 92, no. 11, pp. 2907-2912, Jul. 2011.

[15] S. Rodríguez, "A promising inert support for laccase production and decolouration of textile wastewater by the white-rot fungus trametes pubescesns," Journal of hazardous materials, vol. 233-234, pp. 158-162, Sep. 2012.

[16] M. Čvančarová, Z. Křesinová, A. Filipová, S. Covino, and T. Cajthaml, "Biodegradation of PCBs by ligninolytic fungi and characterization of the degradation products," Chemosphere, vol. 88, no. 11, pp. 1317-1323, Sep. 2012.

[17] A. H. Molla and H. I. Khan, "Detoxification of textile effluent by fungal treatment and its performance in agronomic usages," Environmental Science and Pollution Research, vol. 25, no. 11, pp. 10 820-10 828, Apr. 2018.

[18] P. Blánquez, M. Sarrà, and T. Vicent, “Development of a continuous process to adapt the textile wastewater treatment by fungi to industrial conditions," Process Biochemistry, vol. 43, no. 1, pp. 1-7, Jan. 2008.

[19] D. Bhatia, N. R. Sharma, J. Singh, and R. S. Kanwar, "Biological methods for textile dye removal from wastewater: A review," Critical Reviews in Environmental Science and Technology, vol. 47, no. 19, pp. 1836-1876, Oct. 2017.

[20] R. Taboada and et al., "A new strain of Bjerkandera sp. production, purification and characterization of versatile peroxidase," World Journal of Microbiology and Biotechnology, vol. 27, no. 1, pp. 115-122, Jan. 2011.

[21] Colour Index International, 3rd ed., Society of Dyers and Colourists and AATCC, Bradford, UK, 1987.

[22] M. A. Mazmanci and A. Ünyayar, "Decolourisation of reactive black 5 by Funalia trogii immobilised on Luffa cylindrica sponge," Process Biochemistry, vol. 40, no. 1, pp. 337-342, Jan. 2005.

[23] J. Osorio, "Evaluación de la decoloración de efluentes industriales en un reactor de lecho fijo empleando el hongo de la pudriciòn blanca de la madera antracophyllum discolor," M.S. thesis, Fac. Ing., Universidad de Antioquia, Medellín, Colombia, 2010. 
[24] S. Ntwampe, F. Chowdhury, M. Sheldon, and H. Volschenk, "Overview of parameters influencing biomass and bioreactor performance used for extracellular ligninase production from Phanerochaete chrysosporium," Brazilian Archives of Biology and Technology, vol. 53, no. 5, pp. 1057-1066, Sep. 2010.

[25] J. J. Carberry and R. H. Bretton, "Axial dispersion of mass in flow through fixed beds," AIChE Journal, vol. 4, no. 3, pp. 367-375, Sep. 1958.

[26] M. Zlokarnik, Scale-Up in Chemical Engineering, 2nd ed. Austria: Wiley-Vch, 2002.

[27] E. B. Nauman, Chemical reactor design, optimization and scaleup, 1st ed. New York, USA: McGraw Hill, 2001.

[28] N. Wakao and S. Kaguei, Heat and Mass transfer in packed beds, 1st ed. New York, USA: Gordon and Breach, Science Publishers, 1986.

[29] G. Taylor, "Dispersion of soluble matter in solvent flowing slowly through a tube," Proceedings of the Royal Society A: Mathematical, Physical and Engineering Sciences, vol. 219, no. 1137, pp. 186-203, Aug. 1953.

[30] F. Kuhar, V. Castiglia, and L. Levin, “Enhancement of laccase production and malachite green decolorization by co-culturing Ganoderma lucidum and trametes versicolor in solid-state fermentation," International Biodeterioration \& Biodegradation, vol. 104, pp. 238-243, Oct. 2015.

[31] C. Novotný and et al., "The use of the fungus Dichomitus squalens for degradation in rotating biological contactor conditions," Bioresource Technology, vol. 114, pp. 241-246, Jun. 2012.

[32] Q. Yang, C. Li, H. Li, Y. Li, and N. Yu, “Degradation of synthetic reactive azo dyes and treatment of textile wastewater by a fungi consortium reactor," Biochemical Engineering Journal, vol. 43, no. 3, pp. 225-230, Mar. 2009.

[33] O. M. Gomaa, J. E. Linz, and C. A. Reddy, "Decolorization of victoria blue by the white rot fungus, Phanerochaete chrysosporium," World Journal of Microbiology and Biotechnology, vol. 24, no. 10, pp. 2349-2356, Oct. 2008.
[34] B. Crešnar and S. Petric, "Cytochrome p450 enzymes in the fungal kingdom," Biochimica et Biophysica Acta, vol. 1814, no. 1, pp. 29-35, Jan. 2011.

[35] K. Svobodová, M. Senholdt, . Novotný, and A. Rehorek, "Cytochrome p450 enzymes in the fungal kingdom," Biochimica et Biophysica Acta, vol. 1814, no. 1, pp. 29-35, Jan. 2011.

[36] A. Anastasi and et al., "Scale-up of a bioprocess for textile wastewater treatment using Bjerkandera adusta," Bioresource Technology, vol. 101, no. 9, pp. 3067-3075, May 2010.

[37] H. Bermek, I. Gülseren, K. Li, H. Jung, and C. Tamerler, "The effect of fungal morphology on ligninolytic enzyme production by a recently isolated wood-degrading fungus Trichophyton Rubrum lsk-27," World Journal of Microbiology and Biotechnology, vol. 20, no. 4, pp. 345-349, Jun. 2004.

[38] T. I. Cserháti, E. Forgács, M. H. Morais, and T. Mota, "Liquid chromatography of natural pigments," Biomedical Chromatography, vol. 14, no. 5, pp. 281-286, Aug. 2000.

[39] D. M. Lewis, "The chemistry of reactive dyes and their application processes," in Handbook of textile and industrial dyeing, M. Clark, Ed. Cambridge: woodhead publishing, 2011, pp. 301-359.

[40] F. Lin and et al., "Highly efficient photocatalytic oxidation of sulfurcontaining organic compounds and dyes on $\mathrm{TiO} 2$ with dual cocatalysts Pt and Ru02," Applied Catalysis B: Environmental, vol. 127, pp. 363-370, Oct. 2012.

[41] N. M. I. of Japan(NMIJ). Spectral Database for Organic Compounds SDBS. 2014. [Online]. Available: https://sdbs.db.aist.go.jp/sdbs/ cgi-bin/cre_index.cgi

[42] R. Campos, A. Kandelbauer, K. H. Robra, A. Cavaco, and G. M. Gübitz, "Indigo degradation with purified laccases from Trametes hirsuta and Sclerotium rolfsii," Journal of Biotechnology, vol. 89, no. 1-2, pp. 131-139, Aug. 2001. 